\title{
Histopathologic diagnosis of chronic viral hepatitis
}

\author{
Kronik viral hepatitin histopatolojik tanısı
}

Çiğdem ATAIZİ ÇELIKKEL

\begin{abstract}
Morphological evaluation of the liver continues to play a central role for the diagnosis, grading and staging of chronic viral hepatitis. The defining morphology is necroinflammation, that is hepatocyte injury and inflammation. Hepatocyte injury is usually irreversible, and presents as apoptosis and/or necrosis. Mononuclear cell infiltration of the portal tracts, that is usually accompanied by periportal (interface) and lobular inflammation is typical. Continued necroinflammatory activity at the limiting plate destroying periportal parenchyma initiates fibrogenesis leading to cirrhosis. Fibrosis can be reversible with fragmentation of scar tissue, resolving vascular derangements and parenchymal regeneration. Grading is a measure of the intensity of necroinflammatory activity and staging is a measure of fibrosis and architectural alteration. Besides staging, Laennec scoring system, subdividing cirrhosis that is based on histologic parameters of fibrous septa width and number, has been advised to be used in reporting chronic viral hepatitis.
\end{abstract}

Keywords: Viral hepatitis, Grading, Staging, Biopsy

Çiğdem Ataizi Çelikel (四)

Department of Pathology, School of Medicine, Marmara University Pendik Education and Research Hospital, Istanbul, Turkey

e-mail:cigdemataizi@hotmail.com
ÖZ

Kronik viral hepatit tanısı, derecelendirme ve evreleme açısından, karaciğerin morfolojik değerlendirmesi önem taşır. Tanımsal morfoloji hepatosit hasarı ve inflamasyon ile karakterize nekroinflamasyondur. Hepatosit hasarı, apoptoz ve/veya nekroz şeklinde olup, genellikle geri dönüşümsüzdür. Portal alanda mononükleer hücre infiltrasyonuna, çoğu zaman periportal (interfaz) ve lobüler inflamasyon eşlik eder. İnterfazda periportal hepatositlerde süregelen hasar fibrogenezi tetikler ve siroz gelişebilir. Tamir dokusunun parçalanması, bozulan vaskülatürün organizasyonu ve hepatosit rejenerasyonu ile fibrozis/siroz geri dönüşüm gösterebilir. Nekroinflamasyonun yoğunluğu derecelendirmeyi, fibrozisin dağılımı ve oluşturduğu arkitektürel değişiklikler evreyi tanımlar. Evrelemenin yanısıra, sirotik evrede karaciğerin alt gruplara ayrılmasını tanımlayan Laenec skorlama sisteminin rutin biyopsi değerlendirmesinde uygulanması önerilmektedir.

Anahtar kelimeler: Viral hepatit, Derecelendirme, Evreleme, Biyopsi

\section{Introduction}

Chronic hepatitis $(\mathrm{CH})$ is defined as persistence of liver injury with raised aminotransferase levels and/or viral markers for more than 6 months [1,2]. This definition is actually imperfect, because acute self-limiting hepatitis may prolonge more than 6 months and $\mathrm{CH}$ may have an acute onset $[1,3]$. On the other hand, the term $\mathrm{CH}$ is often restricted to a limited number of causes, but many liver diseases have an inflammatory component (Table I) [1]. Thus, morphological evaluation of the liver continues to play a central role for the diagnosis of $\mathrm{CH}$ and its differentiation from acute hepatitis and other inflammatory diseases of the liver [4,5].

The classification of $\mathrm{CH}$ was first proposed in 1968, that subgrouped patients as chronic active, chronic persistent and chronic lobular hepatitis [6]. Unfortunately, 
this classification has often been misinterpreted as aiming at differentiation between separate disorders rather than just different grades of severity of the same disease process. Since this initial classification, there has been impressive progress in the understanding of $\mathrm{CH}$ including recognition of various causes, pathogenesis and different therapy options. In 1994, two international working parties recommended a predominantly etiological classification, that is supplemented by a semiquantitative scoring [7].

Table I. Chronic hepatitis: differential diagnosis

Classic causes of chronic hepatitis

- Hepatitis B

- Hepatitis B+D

- Hepatitis C

- Autoimmune hepatitis

- Drug-induced hepatitis

- Chronic hepatitis of unknown cause

Conditions sharing pathological features with classic forms of chronic hepatitis

- Wilson's disease

- $\alpha_{1}$-antitrypsin deficiency

- $\quad$ primary biliary cirrhosis

- $\quad$ primary sclerosing cholangitis

Thus, there is a need for liver biopsy in patients with $\mathrm{CH}$ in order to establish the diagnosis, to guide the management by considering the severity of hepatitis (grading), the extent of progression to cirrhosis (staging) and also to determine possible additional pathologic processes (Table II) $[1,3,4]$.

Table II. Role of liver biopsy in chronic hepatitis

- Establishment of the diagnosis

- Clues to aetiology and possible superinfection

- Immunohistochemical assessment of viral antigens

- Diagnosis of additional pathologies/lesions

- Assessment of histological activity (grading)

- Assessment of structural changes (staging)

- Monitoring of therapy

- Description of any putative preneoplastic changes (large cell/small cell dysplasia, dysplastic nodüle)

\section{General Pathology of Chronic Viral Hepatitis}

The morphologic pattern of chronic hepatitis is not spesific for viral hepatitis and may be seen in variety of conditions (Table I) [1,2]. The defining morphology of chronic hepatitis of any cause is necroinflammation, that is hepatocyte injury and inflammation. Hepatocyte injury is usually irreversible, and presents as apoptosis and/or necrosis. Depending on the etiology, reversible injury such as ballooning degeneration, hepatocellular cholestasis and steatosis, can also be seen. All cases of chronic viral hepatitis $(\mathrm{CVH})$ are distinguished by mononuclear cell infiltration of the portal tracts (portal inflammation), that is usually accompanied by periportal (interface) and lobular inflammation. Distribution and density of inflammatory cells may vary from case to case or even in sequential biopsies from the same patients $[1,4,5,8]$.

\section{Portal Inflammation}

The portal tracts may be of normal size or appear widened by the influx of mononuclear cells. The infiltrate includes predominantly CD4+helper/inducer T-lymphocytes with an admixture of plasma cells. In some portal tracts, macrophages containing necrotic hepatocyte debri (diastase resistant, periodic acid-Schiff positive material) can be a component of inflammation. Scattered eosinophils and neutrophils may be present. Lymphoid aggregates or fully formed follicles, although typical for hepatitis $\mathrm{C}$, can also be seen in all forms of viral hepatitis. Inflammation may encroach on the bile ducts, particularly in hepatitis $\mathrm{C}$, leading to damage or even destruction $[5,8,9]$.

\section{Interface Hepatitis}

It is an inflammation and apoptosis affecting the hepatic parenchyma that is in contact with the mesenchymal stroma of the portal tracts (interface). At the interface FAS-ligand positive $\mathrm{CD} 8+$ suppressor/cytotoxic T-cells predominate and lead to apoptosis in hepatocytes forming the limiting plate. Besides apoptosis, hepatocytes in areas of piecemeal necrosis often undergo balloning degeneration, appear pale and swollen, with clumping of cytoplasm. Referring to the way in which the limiting plate was eroded, morphologic appearance is also termed as "piecemeal necrosis" (Figure 1). The term interface hepatitis is now often preferred, because there is evidence to suggest that apoptosis rather than necrosis may be involved in the periportal areas $[1,5,9,10]$. 


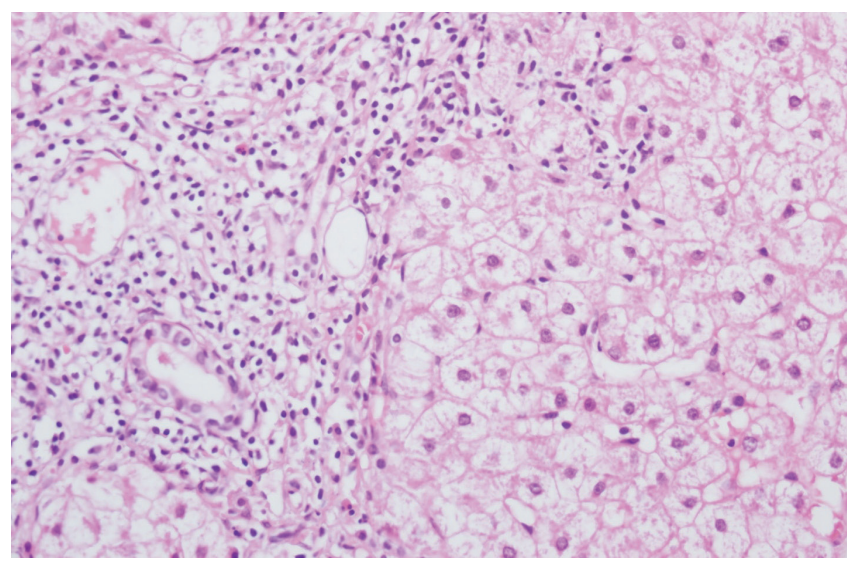

Figure 1. Mild expansion of portal tract with mononuclear cell infiltration and focal piecemeal necrosis (H\&E).

\section{Lobular Necroinflammation}

Hepatocyte apoptosis/necrosis in CVH is variable in severity and it is associated with monunuclear cell response. Isolated apoptotic hepatocytes (acidophilic bodies) can be scattered throughout the lobule. When monunuclear inflammatory cells cluster around injured hepatocytes (either apoptotic or necrotic), it is termed as spotty (focal) necrosis (Figure 2). Kupffer cells in the areas of spotty necrosis may contain phagocytosed cellular debris. Larger areas of hepatocyte loss (area occupied more than five hepatocytes) are referred to as confluent necrosis. Confluent necrosis and collaps that links terminal hepatic venules to portal tracts are termed as bridging necrosis (Figure 3). Panlobular necrosis is rare in $\mathrm{CVH}$. The severity of lobular necroinflammation correlates with the accumulation of progenitor cells in the area of necrosis $[2,3,5,9,10]$.

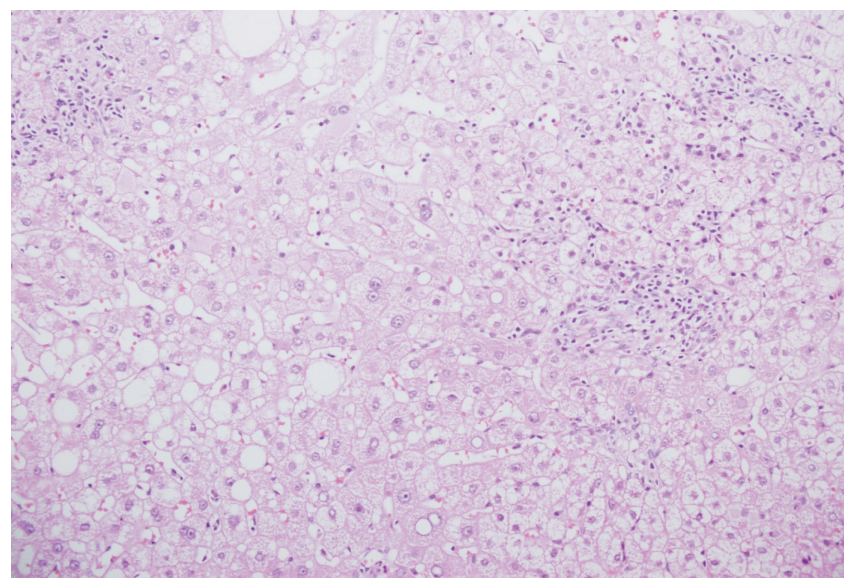

Figure 2. Focal necrosis, ballooning degeneration and nonzonal macrosteatosis that characterize moderate degree of lobular necroinflammation in the liver biopsy of chronic viral hepatitis (H\&E).

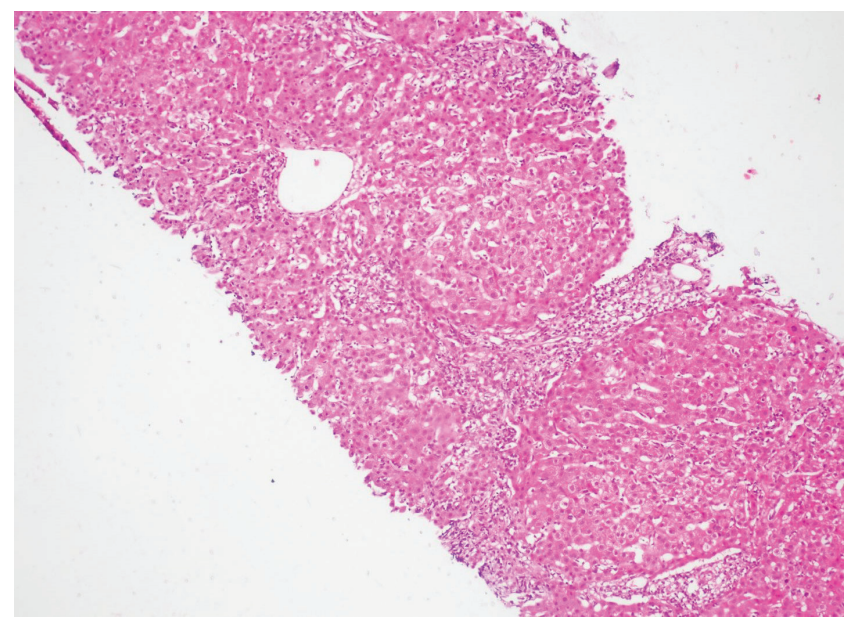

Figure 3. Portal-portal necroinflammation and portal-central bridging necrosis in a case with severe necroinflammation (H\&E).

Other parenchymal changes seen in CVH include ballooning degeneration, steatosis, oncocytic change, and iron deposition. Ballooning degeneration of hepatocytes may be seen in exacerbations of $\mathrm{CVH}$ and can be accompanied by zone 3 bilirubin stasis. Steatosis, although more common in hepatitis $\mathrm{C}$, can also be seen in B and D virus infection (Figure 2). The mechanism for the steatosis may be interference by the viral core protein with lipoprotein assembly and secretion. It is accepted as a risk factor for progression and can interfere therapy. Oncocytic change is due to accumulation of large numbers of closely-packed mitochondria in hepatocytes, with uncertain significance. Siderosis is also more common in hepatitis $\mathrm{C}$, and it influences the progression of liver injury. Iron deposition is not only seen in hepatocytes, but also in macrophages, endothelial cells and portal tracts $[1,3,4]$.

\section{Fibrosis}

In the liver, there is dynamic production and degradation of extracellular matrix at all time points. Development of scarring in a chronically diseased liver is actually the result of a balance in favor of matrix deposition. Continued necroinflammatory activity at the limiting plate (interface) destroying periportal parenchyma initiates fibrogenesis in $\mathrm{CVH}$ and periportal parenchyma is gradually replaced by fibrous tissue leading to stellate enlargement of the portal tracts (Figure 4A). Portal-portal fibrous septa is the result of linkage of adjacent fibrotic portal tracts [11]. Episodes of severe lobular necroinflammatory activity involving zone 3 ends up with the formation of portal-central fibrous septa (bridging fibrosis) (Figure 4B) $[12,13]$. Fibrogenesis in the 
liver causes vascular rearrangement, increased capillary resistance and shunts (arterio-venous and portal-systemic) leading to ischemic changes of the parenchyma. Continued periportal/periseptal necroinflammation and additional ischemic changes accelerates fibrogenesis leading to cirrhosis, which is usually macronodular or mixed microand macronodular in type $[14,15]$. Reliable evaluation of fibrosis, that is collagen deposition, requires connective tissue stains, such as Masson's trichrome stain. In H\&E stained sections, the degree of fibrosis is often underestimated $[8,9,12,13]$. Collagen immunohistochemistry (IHC) stains, mainly collagen type V and VI, may be helpful in the early stages of fibrosis, when trichrome is weak or negative [16].

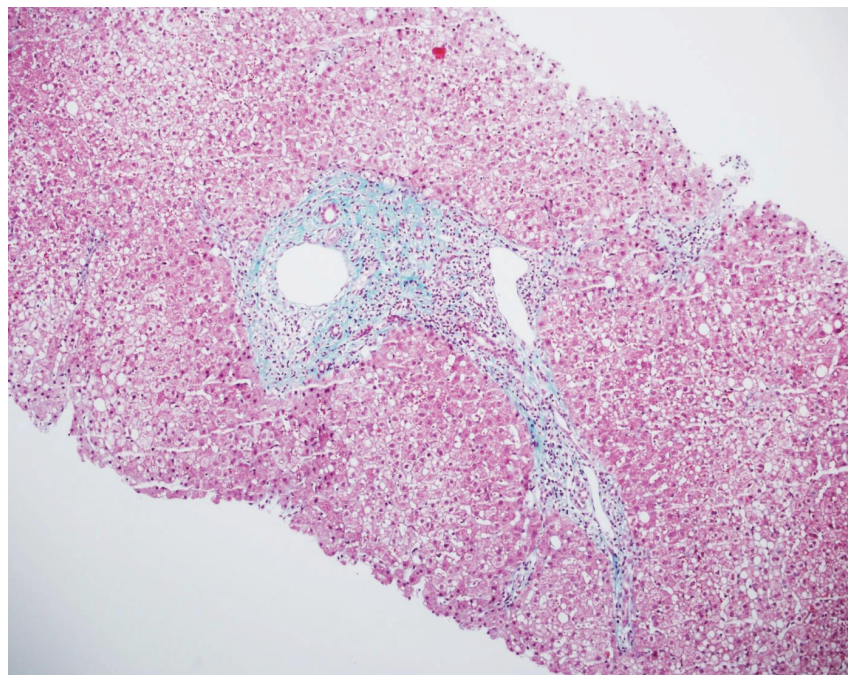

Figure 4. A. Fibrous expansion of portal area due to collagen accumulation

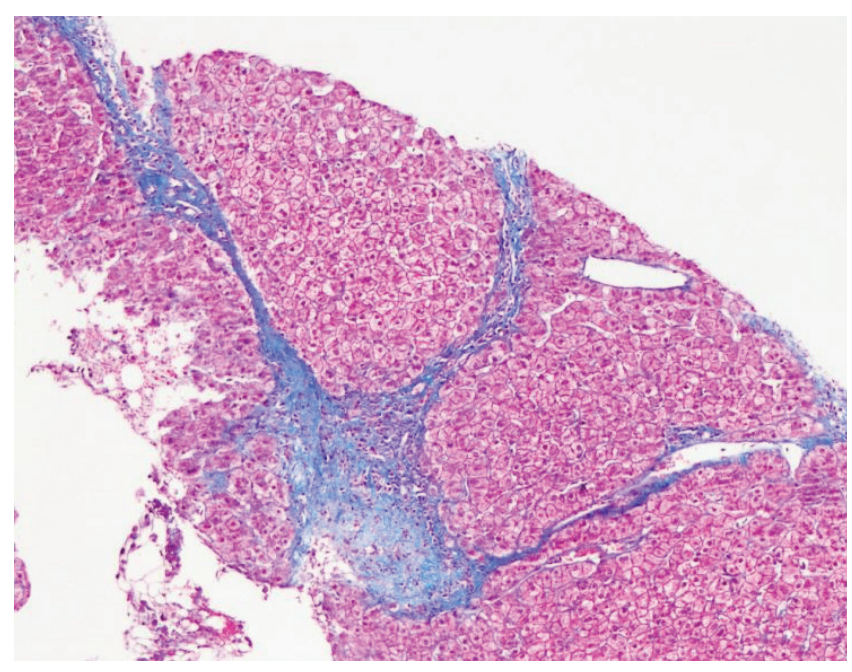

Figure 4. B. Portal-central bridging fibrosis, portal-portal bridging with architectural distortion (Masson trichrome stain).

\section{Cirrhosis}

Cirrhosis by definition is diffuse nodularity of the liver, caused by extracellular matrix deposition leading to parenchymal nodules. The histologic criteria for a diagnosis of cirrhosis are summarized in Table III [1]. In liver biopsies, when there are well-defined rounded nodules surrounded by fibrous septa, the diagnosis is easily established. However, a slender core from within a large cirrhotic nodule can be difficult to identify. In addition, a nodular appearance beneath the liver capsule is not representative of the whole liver and is due to normal septa extending from the liver capsule. So, the ease with which the pathologist can diagnose cirrhosis from biopsy, depends on the size of the biopsy, the type of the biopsy needle used and the area of the liver biopsied. Subcapsular biopsies, thin, and small biopsies are inadequate for the accurate diagnosis of cirrhosis $[1,5,14,17]$.

Table III. Cirrhosis: diagnostic criteria

Fundamental
- Nodularity
- Fibrosis
Relative
- $\quad$ fragmentation
- $\quad$ regnormal structure
- hepatocellular changes (large and small cell dysplasia, ex-
cess copper accumulation)

\section{Regression of Fibrosis and Cirrhosis}

In 2000, Wanless et al documented regression of fibrosis on the sequential biopsies from a CVH-B patient with successful anti-viral therapy [18]. It has now been demonstrated that, in all forms of $\mathrm{CVH}$, fibrosis can regress with elimination of viral activity and infection. Morphologic features of regression, termed as "hepatic repair complex", were described by Wanless et al. Fragmentation-regression of scar (perforated septa, isolated thick collagen fibers, delicate periportal fibrous spikes, hepatocytes within splitting septa), resolving vascular derangements (portal tract remnants, hepatic vein remnants) and parenchymal regeneration (hepatocyte buds) comprise the regenerative phenomena in the liver $[18,19]$. 


\section{Histopathology of Specific Types of Chronic Viral Hepatitis}

\section{Chronic Viral Hepatitis B (CVH-B)}

Both "ground-glass" hepatocytes and "sanded" nuclei are important morphologic clues for hepatitis B infection. Ground-glass appearence in H\&E-stained sections is due to accumulation of hepatitis B surface antigen ( $\mathrm{HBsAg}$ ) in the cytoplasm of hepatocytes (Figure 5). There is a finely granular appearance of the central part of the cytoplasm that is sorrounded by a pale halo. The differential diagnosis of ground-glass hepatocytes includes oncocytic change, drug-induced hypertrophy of the endoplasmic reticulum and from inclusion containing hepatocytes in cyanamide toxicity, Lafora's disease and fibrinogen storage disease. To deliniate this issue, HBsAg can be demonstrated immunohistochemically. Immunoexpression of HBsAg is most abundant in ground-glass hepatocytes, but can also be seen in a membranous or submembranous location in hepatocytes without a ground-glass pattern. Membranous immunostaining is seen in cases of active viral replication in parallel with $\mathrm{HBcAg}$ immunopositivity in the nuclei of hepatocytes. Hepatocyte nuclei which contain large amounts of core protein $(\mathrm{HBcAg})$ have a pale, homogenous appearance on H\&E-stained sections and have been described as "sanded nuclei", that is usually hard to identify. Marked variation in the size/appearance of hepatocyte nuclei and close contact between hepatocytes and lymphocytes (CD8+ type) are other features which characterise CVH-B $[1,5,20,21]$.

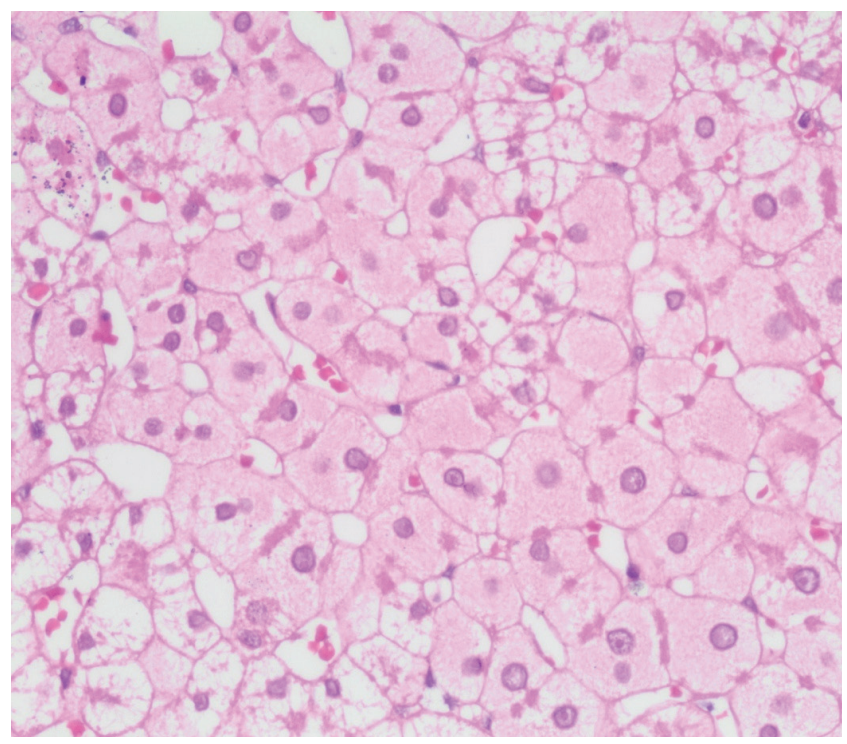

Figure 5. A liver biopsy of chronic hepatitis B; ground glass hepatocytes that contain HBsAg in their cytoplasm (H\&E).
The morphology in liver biopsy in CVH-B depends on the phase (immunotolerant, immune-clearance, or non-replicative) of the hepatitis B virus infection. In immunotolerant phase, although the degree of histologic activity varies, low levels of necroinflammation are more common. Both interface and lobular activity may be seen. Ground-glass hepatocytes and sanded nuclei are abundant and diffuse in distribution. During immune clearance phase, histologic activity is typically high and ground-glass hepatocytes and sanded nuclei are rare. In non-replicative phase, there is low activity with minimal interface hepatitis. Lobular necroinflammation is not necessarily accompanied by portal and periportal inflammation. Ground-glass hepatocytes may be aggregated in focal accumulations $[1,2,3,5]$. Hepatitis B DNA viral load is related with both degree of necroinflammation and fibrosis [21]. Reactivation of virus replication and histologic activity are common and sometimes associated with the emergence of viral mutants. In these cases, in spite of the negative $\mathrm{HBeAg}$ and presence of anti-HBe, histologic activity is unexpectedly high $[1,2,5,22]$.

\section{Chronic Viral Hepatitis B+D $(C V H-B+D)$ :}

Presence of Delta virus is associated with relatively high necroinflammation. Sanded nuclei may be seen and $\mathrm{HBcAg}$ can be demonstrated within the nuclei of hepatocytes by immunohistochemical stains $[1,2,3]$.

\section{Chronic Viral Hepatitis C (CVH-C):}

In $\mathrm{CVH}-\mathrm{C}$, necroinflammation is usually milder than other types of CVH. The presence of steatosis, portal lypmpoid aggregates/follicles, and bile duct damage is suggestive of, but not diagnostic for, CVH-C (Figure 6) [1,5,23].

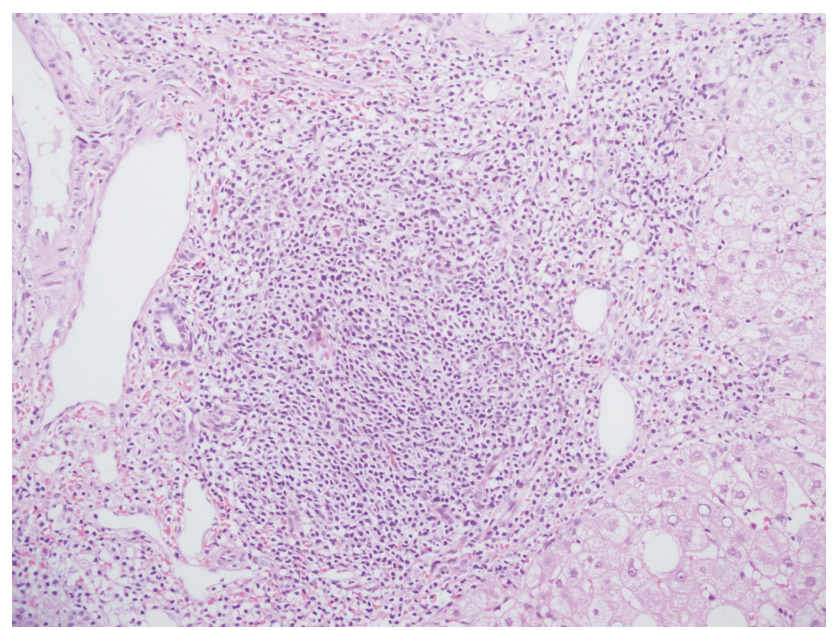

Figure 6. A liver biopsy of chronic hepatitis C; prominant lymphoid aggregates in the portal tracts commonly seen, but not diagnostic for hepatitis $\mathrm{C}$ infection (H\&E). 


\section{Chronic Viral Hepatitis : Grading and Staging}

The purpose of histological scoring (grading and staging) systems is to record histological features which are thought to indicate the severity and progression of $\mathrm{CVH}$. Grading is a measure of the intensity of necroinflammatory activity that includes assessment of portal, periportal and intraacinar inflammatory cell infiltration and various forms of liver cell damage/necrosis. Staging, on other hand, is a measure of fibrosis and architectural alteration $[1,2,5,24]$.

Knodell et al. designed the first formal scoring system, Histologic Activity Index (HAI), specifically for the study of chronic hepatitis, in order to follow the course of asymptomatic patients in whom conventionally used clinical features could not be evaluated [25]. HAI, was based on four components: 1) periportal and bridging necrosis $(0-10), 2)$ intralobular degeneration and focal necrosis (0-4), 3) portal inflammation $(0-4)$, and 4) portal fibrosis (0-4). In a liver biopsy, numerical values alloted for each of these components are added in order to obtain the HAI score (range: 0-22) (Table IV) [25]. A number of criticism have been made for the Knodell HAI scoring system and can be summarized as: 1) discontinuous scale $(0,1,3,4)$ is used for each histological features assessed, 2$)$ scores for portal inflammation involve combining assessments relating to the density within an individual portal area and the overall proportion of the portal tracts involved, which can be misleading in small biopsies, 3 ) it combines interface hepatitis with bridging necrosis, the latter is accepted as a manifestation of lobular activity and should be assessed separately, 4) scores of activity are combined with scores for fibrosis [26]. In recognition of these problems, Ishak and colleagues modified Knodell system in 1995 (Tables V and VI) [27]. The system proposed by Ishak et al. incorporates current concepts relating to the pathogenesis of liver damage in $\mathrm{CVH}$ by providing a wide range of possible scores (Tables V and VI) [27].

Table IV. Knodell et al. (1981) ; Histologic Activity Index (HAI) [25]

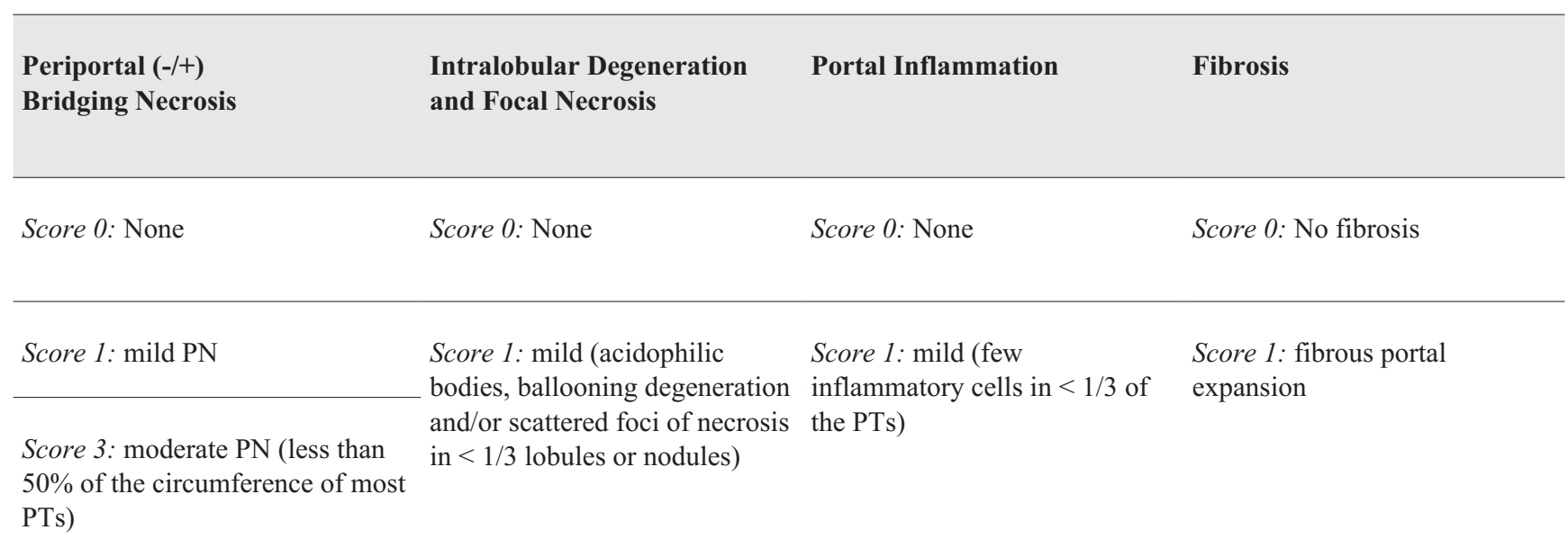

Score 4: marked PN (more than Score 3: moderate (involvement Score 3: moderate (increased Score 3: bridging fibrosis $50 \%$ of the circumference of most of 1/3-2/3 lobules or nodules) inflammatory cells in 1/3-2/3 of (portal-portal or portal-central) PTs)

Score 5: moderate PN (+)

bridging necrosis the PTs)
Score 6: marked PN $(+)$ bridging Score 4: marked (involvement necrosis of $>2 / 3$ lobules or nodules)
Score 4: marked (numerous inflammatory cells in $>2 / 3$ of the PTs)
Score 4: cirrhosis

Score 10: multilobular necrosis 
Table V. Ishak et al. (1995) Grading; Modified Histologic Activity Index [27]

\author{
A.Periportal or periseptal interface hepatitis (piecemeal nec- \\ rosis) \\ Score 0: Absent \\ Score 1: Mild (focal, few portal areas) \\ Score 2: Mild/moderate (focal, most portal areas) \\ Score 3: Moderate (continuous around $<50 \%$ of tracts or septa) \\ Score 4: Severe (continuous around $>50 \%$ of tracts or septa)
}

\section{B.Confluent necrosis}

Score 0: Absent

Score 1: Focal confluent necrosis

Score 2: Zone 3 necrosis in some areas

Score 3: Zone 3 necrosis in most areas

Score 4: Zone 3 necrosis + occasional portal-central bridging

Score 5: Zone 3 necrosis + multipl portal-central bridging

Score 6: Panacinar or multiacinar necrosis

\section{C.Focal necrosis, apoptosis and focal inflammation}

Score 0: Absent

Score 1: $\leq 1$ focus per 10X objective

Score 2: 2-4 foci per 10X objective

Score 3: 5-10 foci per 10X objective

Score 4: $>10$ foci per $10 \mathrm{X}$ objective

\section{C.Portal inflammation}

Score 0: None

Score 1: Mild, some or all portal areas

Score 2: Moderate, some or all portal areas

Score 3: Moderate/marked, all portal areas

Score 4: Marked, all portal areas

Maximum possible score: 18

Table VI. Ishak et al. (1995) Modified Staging: architectural changes, fibrosis and cirrhosis [27]

Stage 0: No fibrosis

Stage 1: Fibrous expansion of some portal areas,(-/+) short septa

Stage 2: Fibrous expansion of most portal areas,(-/+) short septa

Stage 3: Fibrous expansion of most portal areas, $(+)$ occasional portal-portal bridging

Stage 4: Fibrous expansion of most portal areas, $(+)$ marked portal-portal as well as portal-central bridging

Stage 5: Marked bridging with occasional nodules (incomplete cirrhosis)

Stage 6: Cirrhosis, probable or definite

Maximum possible score : 6
Simplified scoring systems, such as Scheuer [28], Batts/ Ludwig [29] and METAVIR [30], are notable among the several other scoring systems and may be more appropriate to use in daily pathology practice (Tables VII and VIII). These systems do not score portal inflammation in line with the conviction that regardless of severity of portal inflammation, in absence of interface hepatitis, coincides with low risk of fibrosis $[1,5,26]$. METAVIR system, designed by French pathologists in CVH-C patients, uses an algorithmic approach to determine necroinflammatory score [30]. An important feature of these systems recognized that grading of necroinflammatory activity should be seperated from staging. The main criticism to these simplified systems is the production of a narrower range of potential scores, which limits their usefulness in the context of monitoring response to therapy in clinical trials $[5,26]$.

As some of them mentioned above, each of these systems has special strenghts and weaknesses, but in all of them there is a fundamental problem. That is, assessment scores of each individual categories of necroinflammation, which may have different pathogenetic mechanisms and prognostic significance, are added together. The total score generated do not represent measurements of a continuous variable, and cannot be regarded as mathematically valid (Figure 7) [26]. Besides, there are problems of inter-observer variation which stem partly from imprecise terminology defining individual histological features [31,32]. In general, in each of the scoring systems used, better reproducibility has been obtained for scoring fibrosis than for scoring necroinflammation (31). In a study to identify the sources of variability, the level of experience was found to have more influence on agreement than the characteristics of the specimen $[32,33]$. Evaluation of the liver biopsy by an experienced liver pathologists is important in order to design the therapy in a CVH patient [33].

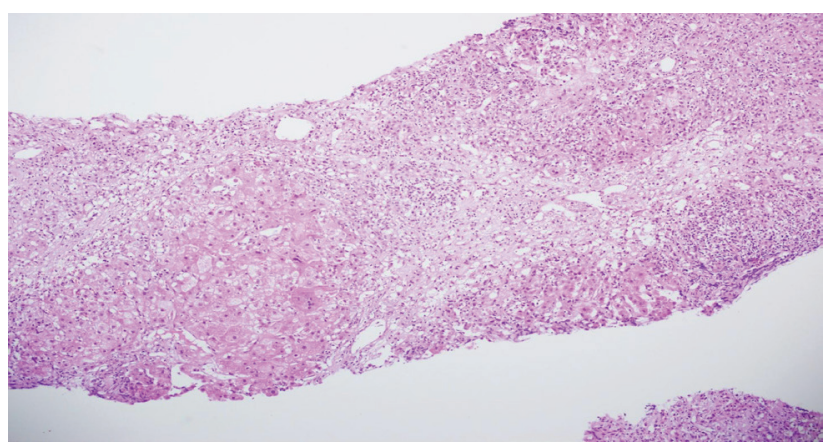

Figure 7. Marked confluent necrosis leading to portal-central bridging necrosis, and portal-portal bridging with prominant interface activity; Knodell HAI- periportal (-/+) bridging necrosis: Score:6; Ishak Modified HAI- interface hepatitis: score4 (+) confluent necrosis: score 5 (H\&E). 
Table VII. Comparison of simple grading systems

\begin{tabular}{|c|c|c|c|}
\hline $\begin{array}{l}\text { Grading } \\
\text { Scheme }\end{array}$ & Parameters Scored & Scale Used & Overall Grade \\
\hline Scheuer (28) & $\begin{array}{l}\text { Portal/periportal activity } \\
\text { Lobular activity }\end{array}$ & $\begin{array}{l}0-4 \\
0-4\end{array}$ & sum of individual scores (range: $0-8$ ) \\
\hline Batts \& Ludwig (29) & $\begin{array}{l}\text { Piecemeal necrosis } \\
\text { Lobular necroinflammation }\end{array}$ & $\begin{array}{l}\text { none, minimal, mild, } \\
\text { moderate, severe } \\
\text { none, minimal, mild, } \\
\text { moderate, severe }\end{array}$ & $\begin{array}{l}\text { severity of lesion (periportal or lobular) } \\
\text { determines grade }\end{array}$ \\
\hline $\begin{array}{l}\text { Bedossa \& Poynard } \\
\text { (METAVIR) [30] }\end{array}$ & $\begin{array}{l}\text { Piecemeal necrosis } \\
\text { Lobular necrosis }\end{array}$ & $\begin{array}{l}0-3 \text { (none, mild, moderate, } \\
\text { severe) } \\
0-3 \text { (none, mild, moderate, } \\
\text { severe) }\end{array}$ & $\begin{array}{l}\text { Algorithm combining piecemeal }+ \text { lobular } \\
\text { necrosis (A0:none, A1:mild, } \\
\text { A2:moderate, A3: severe) }\end{array}$ \\
\hline
\end{tabular}

Table VIII. Comparison of staging systems

\begin{tabular}{llllll}
\hline Grading Scheme & Stage 0 & Stage 1 & Stage 2 & Stage 3 & Stage 4 \\
\hline Scheuer [28] & no fibrosis & $\begin{array}{l}\text { enlarged fibrotic } \\
\text { portal tracts }\end{array}$ & $\begin{array}{l}\text { periportal fibrosis or } \\
\text { porto-portal septa }\end{array}$ & $\begin{array}{l}\text { fibrosis with } \\
\text { architectural distortion }\end{array}$ & $\begin{array}{l}\text { cirrhosis (probable/ } \\
\text { definite) }\end{array}$ \\
\hline Batts and Ludwig [29] & no fibrosis & portal fibrosis & $\begin{array}{l}\text { periportal fibrosis (rare } \\
\text { porto-portal septa) }\end{array}$ & $\begin{array}{l}\text { septal fibrosis (with } \\
\text { architectural distortion) }\end{array}$ & cirrhosis \\
\hline $\begin{array}{l}\text { Bedossa and Poynard } \\
\text { no fibrosis }\end{array}$ & $\begin{array}{l}\text { portal fibrosis, } \\
\text { without septa }\end{array}$ & $\begin{array}{l}\text { portal fibrosis, with rare } \\
\text { septa }\end{array}$ & $\begin{array}{l}\text { numerous septa, } \\
\text { without cirrhosis }\end{array}$ & cirrhosis \\
\hline
\end{tabular}

\section{Staging Cirrhosis}

Cirrhosis has been widely regarded as an irreversible end-stage liver disease. However, recent studies have demonstrated with serial liver biopsies that fibrosis may also decrease with time in some cirrhotic livers [18]. Specific morphological changes that are associated with irreversibility include: thickness of collagen bands, elastinrich scars, matrix modification with cross linking (the type of collagen deposition), the loss of hepatocytes that limit regeneration and loss of cells that drive matrix turnover from the septa combined with vascular extinction [17]. Since various clinical stages do exist and regression of fibrosis can be detected in cirrhotic patients, further subclassification of histology of cirrhosis seems necessary $[17,18]$. For semiquantitative estimation, Laennec Staging System, that is based on histologic parameters of fibrous septa width and number has been proposed (Figure 8) [34]. The Laennec system subdivides the highest fibrosis stage of 4 (in 4-tier systems) as $4 \mathrm{~A}, 4 \mathrm{~B}$, and $4 \mathrm{C}$ in order to recognize the variable distribution, maturation and amount of fibrosis in cirrhotic livers (Table VIII) [34]. Histologic subclassification of cirrhosis by the Laennec Staging System have been shown to be tightly correlated with both the clinical stage of cirrhosis and grade of portal hypertension [34-37]. 

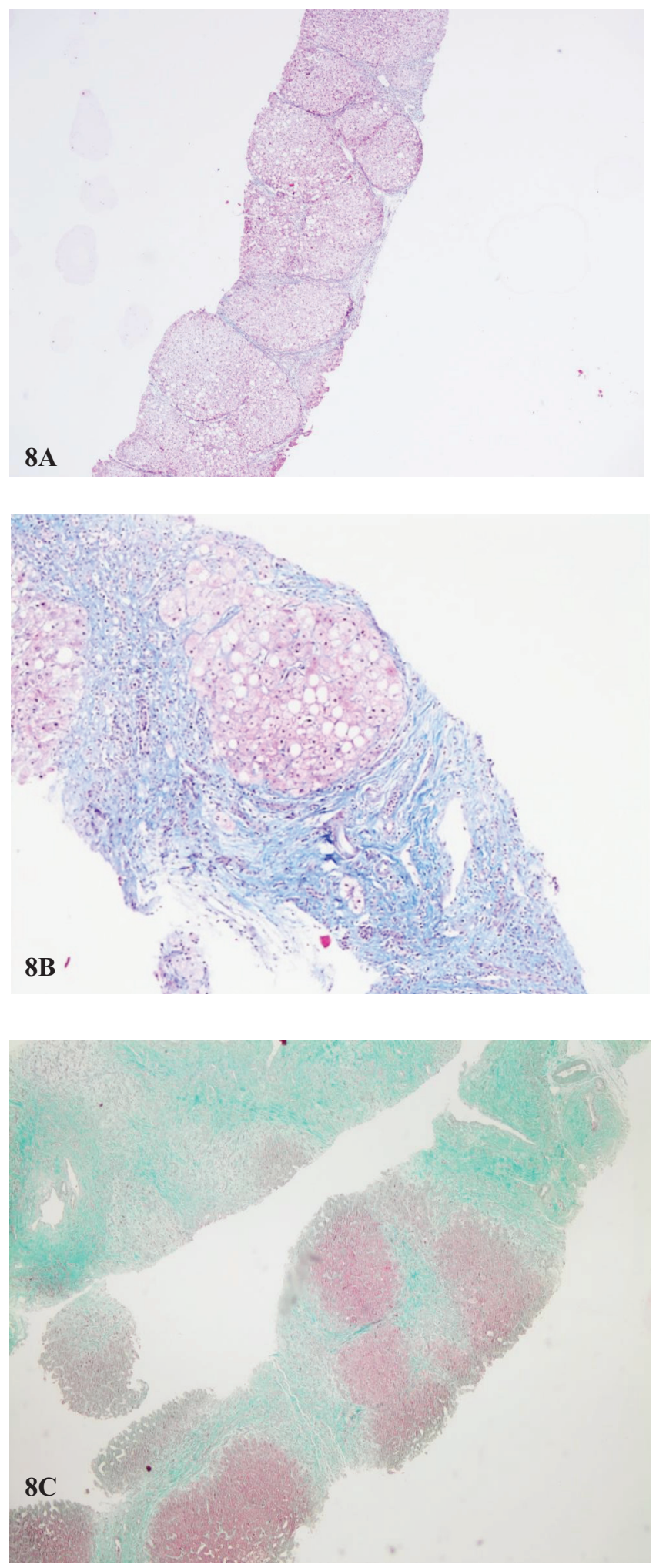

Figure 8. Histologic subclassification of cirrhosis by the Laennec Staging System in 4-tier staging system A. marked septation with rounded contours of visible nodules, most septa are thin (Stage:4A); B and C. very broad fibrous septa with more than half of biopsy length composed of minute nodules and fibrous scar (Stage:4C) (Masson trichrome stain).
Table IX. Laennec scoring system for staging fibrosis in liver biopsies [34].

\begin{tabular}{|c|c|c|c|}
\hline Stage & Name & Septa & Criteria \\
\hline $\mathbf{0}$ & No fibrosis & - & \\
\hline 1 & $\begin{array}{l}\text { Minim a } 1 \\
\text { fibrosis }\end{array}$ & $+/-$ & $\begin{array}{l}\text { No septa or rare thin septum; } \\
\text { may have portal expantion or } \\
\text { mild sinusoidal fibrosis }\end{array}$ \\
\hline 2 & $\begin{array}{l}\text { Mild fibro- } \\
\text { sis }\end{array}$ & + & $\begin{array}{l}\text { Occasional thin septa; may } \\
\text { have portal expantion or mild } \\
\text { sinusoidal fibrosis }\end{array}$ \\
\hline 3 & $\begin{array}{l}\text { Moderate } \\
\text { fibrosis }\end{array}$ & ++ & $\begin{array}{l}\text { Moderate thin septa; up to in- } \\
\text { complete cirrhosis }\end{array}$ \\
\hline $4 A$ & $\begin{array}{l}\text { Cirrhosis, } \\
\text { mild (defi- } \\
\text { nite or pro- } \\
\text { bable) }\end{array}$ & +++ & $\begin{array}{l}\text { Marked septation with roun- } \\
\text { ded contours or visible nodu- } \\
\text { les, most septa are thin (one } \\
\text { broad septum allowed) }\end{array}$ \\
\hline 4B & $\begin{array}{l}\text { Moderate } \\
\text { cirrhosis }\end{array}$ & ++++ & $\begin{array}{l}\text { At least two broad septa, but } \\
\text { no very broad septa and less } \\
\text { than half of biopsy length } \\
\text { composed of minute nodules }\end{array}$ \\
\hline $4 C$ & $\begin{array}{l}\text { Severe cir- } \\
\text { rhosis }\end{array}$ & +++++ & $\begin{array}{l}\text { At least one very broad sep- } \\
\text { tum or more than half of bi- } \\
\text { opsy length composed of mi- } \\
\text { nute nodules (micronodular } \\
\text { cirrhosis) }\end{array}$ \\
\hline
\end{tabular}

\section{Differential Diagnosis}

Morphologic differentiation of $\mathrm{CVH}$ from acute hepatitis depends on the presence of fibrosis in $\mathrm{CVH}$. While the parenchymal changes predominate in acute hepatitis, especially in perivenular areas, portal and periportal changes predominate in $\mathrm{CVH}$. Bridging necrosis that can be seen in both acute and chronic hepatitis may be mistaken for bridging septa of $\mathrm{CVH}$. This problem can be solved by elastic stains, such as Victoria blue, which is negative in acute, but positive in mature septa of CVH $[1,3,4]$.

Any disease leading to dense lymphoplasmocytic infiltrate in the portal tracts may mimic $\mathrm{CVH}$, such as autoimmune hepatitis, primary biliary cirrhosis(PBC), drug induced liver diseases and lymphomas [1-5]. Cases of $\mathrm{CVH}$ (mainly CVH-C) with antinuclear antibody (ANA) positivity may also mimic autoimmune hepatitis, clinically $[38,39]$. As a rule CVH-C lacks the prominent plasma cell infiltrate and severe necroinflammatory activity typically seen in autoimmune hepatitis, but the differential diagnosis 
can be difficult in some cases [1]. Early lesions of PBC may mimic CVH. Destruction and/or loss of bile ducts, cholate stasis and accumulation of copper-associated protein in periportal hepatocytes suggest biliary disease [3]. Drugs sometimes cause confusion in the diagnosis, but with clinical correlation and laboratory findings this issue can easily be solved $[1,2,5]$. Lymphoma or leukemic infiltrates may also mimic $\mathrm{CVH}$, particularly when the infiltrate is most predominantly located in the portal tracts. In these cases monomorphism and marked atypia of inflammatory cells favor lymphoma/leukemia [2].

\section{Adequacy of Liver Biopsy}

Ideal length of a liver biopsy is $3.0 \mathrm{~cm}$ and it must be obtained with a 16 gauge needle. If cirrhosis is suspected, a cutting needle rather than a suction needle should be used [40, 41]. In CVH, accuracy in grading and staging is reduced in biopsies less than $2.0 \mathrm{~cm}$ in lenght, and needle biopsy specimens measuring less than $1.5 \mathrm{~cm}$ in lenght are accepted as unreliable to determine grade and stage of $\mathrm{CVH}$ [42-44]. If the lenght of liver biopsy is less than $1.5 \mathrm{~cm}$ and/or liver biopsy contains less than 11 complete portal areas, it must be noted in the pathology report, and the clinicians must recognize that the diagnosis, grading and staging may be incorrect due to an insufficient sample size $[40,41]$. A biopsy with adequate size represents only one hundred thousandth of the whole liver, and sampling variability appears to be a limitation in scoring $\mathrm{CVH}$ [45]. In $\mathrm{CVH}$ patients biopsies taken from left and right liver lobe showed discordant results in $33 \%$ of the cases by at least one histologic stage. In smaller biopsies this discordance was by at least two stages [46].

\section{Key Points}

- Necroinflammation determined as hepatocyte injury and inflammation is the main pathology of chronic viral hepatitis.

- Continued necroinflammatory activity at the limiting plate destroying periportal parenchyma initiates fibrogenesis leading to cirrhosis.

- Grading is a measure of the intensity of necroinflammatory activity and staging is a measure of fibrosis and architectural alteration

- Fibrosis can be reversible with fragmentation of scar tissue, resolving vascular derangements and parenchymal regeneration

\section{References}

1. Scheuer PJ, Lefkowitch JH. Chronic hepatitis. In: Scheuer PJ, Lefkowitch JH, eds. Liver Biopsy Interpretation, $7^{\text {th }}$ ed. Elsevier Saunders, 2005: 145-170.

2. Theise ND, Bodenheimer HC, Ferrell LD. Acute and chronic viral hepatitis. In: Burt AD, Portmann BC, Ferrell L, eds. MacSween's Pathology of the Liver, $6^{\text {th }}$ ed. Edinburg: Churchill-Livingstone-Elsevier, 2012:361-402.

3. Hytiroglou P. Hepatitis B and C. In: Saxena R, ed. Practical Hepatic Pathology, 1 $^{\text {th }}$ ed. Elsevier Saunders, 2011: 215-234.

4. Yerian LM, Lamps LW. Acute and chronic infectious hepatitis. In: Odze DR, Goldblum JR, eds. Surgical Pathology of the GI Tract, Liver, Biliary Tract, and Pancreas, $3^{\text {rd }}$ ed. Philedelphia: Elsevier Saunders, 2015:1228-1261.

5. Guido M, Mangia A, Faa G. Chronic viral hepatitis: The histology report. Dig Liver Dis 2011;43:S331-S343.

6. De Groote J, Desmet VJ, Gedigk P, et al. A classification of chronic hepatitis. Lancet 1968;2:262-8.

7. Ludwig $\mathrm{J}$, McFarlane IG, Rakela $\mathrm{J}$ and the International Working Party. Terminology of chronic hepatitis. Am J Gastroenterol 1995;90:181-9.

8. Crawford JM, Burt AD. Anatomy, pathophysiology and basic mechanisms of disease. In: Burt AD, Portmann BC, Ferrell L, eds. MacSween's Pathology of the Liver, $6^{\text {th }}$ ed. Edinburg: Churchill-Livingstone-Elsevier, 2012: 1-77.

9. Theise ND. Liver biopsy assessment in chronic viral hepatitis: a personal, practical approach. Modern Pathol 2007;20:S3S14.

10. Schattenberg JM, Galle PR, Schuchmann M. Apoptosis in liver disease. Liver Int 2006;26:904-11.

11. Hano H, Takasaki S, Endo Y, Harada T, Komine K, Koike Y. Histologic reassessment of the role of bridging fibrosis in the angioarchitectural features associated with lobular distortion of the liver in chronic viral hepatitis. Hepatol Res 2016;46:E70-8.

12. Friedman SL. Mechanisms of hepatic fibrogenesis. Gastroenterol 2008;134:1655-69.

13. Iwaisako K, Brenner DA, Kisseleva T. What's new in liver fibrosis? The origin of myofibroblasts in liver fibrosis. J Gastroenterol Hepatol 2012;27(suppl 2):65-68.

14. Wanless IR, Huang WY. Vascular disorders. In: Burt AD, Portmann BC, Ferrell L, eds. MacSween's Pathology of the Liver, $6^{\text {th }}$ ed. Edinburg: Churchill-Livingstone-Elsevier, 2012:601-43.

15. Elpek GÖ. Angiogenesis and liver fibrosis. World J Hepatol 2015;7:377-91.

16. Chen W, Rock JB, Yearsley MM, Ferrell LD, Frankel WL. Different collagen types show distinct rates of increase from early to late stages of hepatitis C-related liver fibrosis. Human Pathol 2014;45:160-5.

17. Garcia-Tsao G, Iredale J, Pinzani. Now there are many (stages) where before there was one: in search of a pathophysiological classification of cirrhosis. Hepatology 2010;51:1445-9.

18. Wanless IR, Nakashima E, Sherman M. Regression of human cirrhosis. Arch Pathol Lab Med 2000;124:1599-1607.

19. Friedman SL. Fibrogenic cell reversion underlies fibrosis regression in liver. Proc Natl Acad Sci 2012;109:9230-1.

20. Mani H, Kleiner DE. Liver biopsy findings in chronic hepatitis B. Hepatology 2009;49:S61-S71. 
21. Biazar T, Yahyapour Y, Roushan H, et al. Relationship between hepatitis B DNA viral load in the liver and its histology in patients with chronic hepatitis B. Caspian J Intern Med 2005;6:209-12.

22. Tachtatzis PM, Marshall A, Arvinthan A, et al. Chronic hepatitis B virus infection: the relation between hepatitis $\mathrm{B}$ antigen expression, telomere length, senescence, inflammation and fibrosis. PLoS One 2015;10:e0127511.

23. Fiel MI. Pathology of chronic hepatitis B and chronic hepatitis C. Clin Liver Dis 2019;14:555.

24. Desmet VJ, Gerber M, Hoofnagle JH, Manns M, Scheuer PJ. Classification of chronic hepatitis: diagnosis, grading and staging. Hepatology 1994;19:1513-20.

25. Knodell RG, Ishak KG, Black WC, et al. Formulation and application of a numerical scoring system for assessing histological activity in asymptomatic chronic active hepatitis. Hepatology 1981;1:431-5.

26. Hübscher SG. Histological grading and staging in chronic hepatitis: clinical applications and problems. J Hepatol 1998;29:1015-22.

27. Ishak K, Baptista A, Bianchi L, et al. Histological grading and staging of chronic hepatitis. J Hepatol 1995;22:696-9.

28. Scheuer PJ. Classification of chronic viral hepatitis: a need for reassessment. J Hepatol 1991;13:372-4.

29. Batts KP, Ludwig J. Chronic hepatitis: an update on terminology and reporting. Am J Surg Pathol 1995;19:140917.

30. Bedossa P, Poynard T and the French METAVIR Cooperative Study Group. An algorithm for grading activity in chronic hepatitis C. Hepatology 1996;24:289-93.

31. Goldin RD, Goldin JG, Burt AD, Dhillon PA, Wyatt J, Patel N. Intra-observer and inter-observer variation in the histopathological assessment of chronic viral hepatitis. J Hepatol 1996;25:649-54.

32. Rousselet MC, Michalak S, Dupre F, et al. Sources of variability in histological scoring of chronic viral hepatitis. Hepatology 2005;41:41:257.

33. Paterson AL, Allison ME, Brais R, Davies SE. Any value in a specialist review of liver biopsies? Conclusions of a four-year review. Histopathology 2016 Jan 30. [Epub ahead of print]

34. Kutami R, Girgrah N, Wanless IR, et al. The Laennec grading system for assessment of hepatic fibrosis: validation by correlation with wedged hepatic vein pressure and clinical features. Hepatology 2000;32:407A.

35. Hytiroglu P, Snover DC, Alves V, et all. Beyond "Cirrhosis": A proposal from international liver pathology subgroup. Am J Clin Pathol 2012;137:5-9.

36. Kim SU, Oh HJ, Wanless IR, Lee S, Han H, Park YN. The Laennec staging system for histological sub-classification of cirrhosis is useful for stratification of prognosis in patients with liver cirrhosis. J Hepatol 2012;57:556-63.

37. Kim SU, Cho MY, Baik SK, et al. Histological subclassification of cirrhosis using the Laennec fibrosing scoring system correlates with clinical stage and grade of portal hypertension. J Hepatol 2011;55:1004-9.

38. Narciso-Schiavon JL, Freire FC, Suarez MM, et al. Antinuclear antibody positivity in patients with chronic hepatitis $\mathrm{C}$; clinically relevant or an epiphenomenon? Eur J Gastroenterol Hepatol 2009;21:440-6.

39. Li BA, Liu J, Hou J, et al. Autoantibodies in Chinese patients with chronic hepatitis B: prevalence and clinical associations. World J Gastroenterol 2015;21:283-91.

40. Rockey DC, Caldwell SH, Goodman ZD, Nelson RC, Smith AD. Liver biopsy. Hepatology 2009;49:1017-43.

41. Cholongitas E, Senzolo M, Standish R, et al. A systematic review of the quality of liver biopsy specimens. Am J Clin Pathol 2006;125:710-21.

42. Colloredo G, Guidon M, Sonzogni A, Leandro G. Impact of liver biopsy size on histological evaluation of chronic viral hepatitis: the smaller the sample, the milder the disease. J Hepatol 2003;39:239-44.

43. Schiano TD, Azeem S, Bodian CA, et al. Importance of specimen size in accurate needle biopsy evaluation of patients with chronic hepatitis C. Clin Gastroenterol Hepatol 2005;3:930-5.

44. Bedossa P, Dargere D, Paradis V. Sampling variability of liver fibrosis in chronic hepatitis C. Hepatol 2003;38:1449.

45. Bravo AA, Sheth SG, Chopra S. Liver biopsy. N Eng J Med 2001;344:495-500.

46. Skripenova S, Trainer T, Krawitt E, Blaszyk H. Variability of grade and stage in simultaneous paired liver biopsies in patients with hepatitis C. J Clin Pathol 2007;60:321-4. 